\title{
IMPLEMENTATION EVALUATION OF THE FORESTRY PARTNERSHIP IN THE TARAKAN ISLAND PROTECTED FOREST REGIONAL TECHNICAL IMPLEMENTATION UNIT - TARAKAN FOREST MANAGEMENT UNIT
}

\author{
Rositah E. ${ }^{1,3 *}$, Sardjono M.A. ${ }^{1}$, Aipassa M.I. ${ }^{1}$, Suyadi ${ }^{2}$, \\ Hernandi M.F. ${ }^{4}$, Zarta A.R. ${ }^{4}$, Wartomo ${ }^{4}$ \\ ${ }^{1}$ Faculty of Forestry, Mulawarman University, East Kalimantan, Indonesia \\ ${ }^{2}$ Faculty of Agriculture, Mulawarman University, East Kalimantan, Indonesia \\ ${ }^{3}$ Department of Forest Management, Samarinda State of Agriculture Polytechnic, \\ East Kalimantan, Indonesia \\ ${ }^{4}$ Department of Forest Product Technology, Samarinda State of Agriculture Polytechnic, \\ East Kalimantan, Indonesia \\ ${ }^{*}$ E-mail: ernarositah7@gmail.com
}

\begin{abstract}
The function of the Tarakan Island Protected Forest (HLPT) continues to undergo pressure by conflicts that have an impact on its existence and potentially cause a clean water crisis for the people of Tarakan City. Forestry partnership as a conflict resolution effort, in its implementation, requires an evaluation in the form of an assessment to see the conditions of the ongoing partnership. The research objective was to evaluate the implementation of forestry partnerships in HLPT. The research was carried out in 2020 at the Tarakan Forest Management Unit (KPH Tarakan) HLPT with a focus on Association of Forest Farmers Group (Gapoktanhut) and Regional Technical Implementation Unit - Tarakan Forest Management Unit (UPTD KPH Tarakan). The collection of data/information was carried out through interviews, FGDs, and documentation studies with qualitative descriptive analysis. Implementation evaluation of the forestry partnership in HLPT is carried out on aspects of land management, institutions, human resource capacity of the community, and the UPTD $\mathrm{KPH}$ Tarakan as well as monitoring and evaluation. All aspects with their indicators show the gap between the current condition and the expected ideal condition. Strengthening and mentoring need to be done to achieve the objectives of the forestry partnership in HLPT.
\end{abstract}

\section{KEY WORDS}

Evaluation, forestry partnerships, Tarakan Island, protected forest, UPTD KPH Tarakan, community.

HLPT has an important and strategic role in supporting the life of the people of Tarakan City, especially its role as a source of raw water. The threat to forest sustainability means that it has the potential to cause a clean water crisis. On the other hand, social and economic problems, especially for people who have been using protected forests for various business activities and settlements, cannot be ignored.

The problems faced in the management of HLPT include (1) the problem of area certainty, especially in the outer boundaries of the area which have not been fully resolved. This could result in or even spread conflicts over land and resources; (2) land tenure claims (certificate of ownership rights, customary land) still occur not only in areas around settlements but also in forest areas, including those with utilization/use permits (Anonymous, 2014). Unclear regional boundaries and unfair distribution and community access to forest resources are the most prominent causes of conflict in the field (Yusran, 2012)

Empowerment of local communities through a partnership scheme that concretely places the position of the community as one of the important actors in forest management to increase the capacity and independence of the community to obtain optimal and equitable benefits of forest resources by prioritizing the principles of partnership. Participatory planning, support, and commitment of the parties, implementation, monitoring, and evaluation which are carried out consistently and continuously are important factors in 
supporting the success of forestry partnerships. In the implementation process, evaluation is needed to see the position and problems faced at this time as a basis for making improvements and strengthening. This research aims to evaluate the implementation of forestry partnerships in HLPT.

\section{METHODS OF RESEARCH}

The research was conducted at HLPT UPTD KPH Tarakan with a focus on community members of Gapoktanhut and UPTD KPH Tarakan. Research began in March 2020.

Data/information collection was carried out by a combination of several techniques, namely in-depth interviews, focus group discussions, documentation studies of members of the Gapoktanhut group, and the UPTD KPH Tarakan. The analysis was carried out in a descriptive qualitative manner. Evaluation of the implementation of forestry partnerships is carried out using a gap analysis by looking at the position of the current partnership capacity against the expected ideal conditions. The analysis uses a range of levels $1-4$, where level 4 is an ideal condition that is expected to guarantee the successful implementation of forestry partnerships in HLPT.

Table 1 - Forestry Partnership Capacity Gap Analysis Metric

\begin{tabular}{|c|c|c|c|c|c|}
\hline Aspect & Indicator & \multicolumn{4}{|c|}{ Level } \\
\hline Land governance & & 1 & 2 & 3 & 4 \\
\hline Institutions & & & & & \\
\hline HR capacity & & & & & \\
\hline Monitoring and evaluation & & & & & \\
\hline
\end{tabular}

\section{RESULTS AND DISCUSSION}

Conflict resolution applied in resolving HLPT management conflicts is by implementing a social forestry program. Social forestry policies can provide legal certainty, access to forest area land, community business development, improved forest governance, and conflict resolution. This program also has three pillars in its implementation, namely land, business opportunities, and human resources.

The forestry partnership is seen as the most realistic as an effort to maintain and restore the ecological conditions of the HLPT while maintaining the economic resources of the community in the area. The implementation of forestry partnerships in addition to providing access to local communities to obtain beneficial values from forest resources is also an effort to resolve conflicts that occur between forest managers and/or permit holders and the surrounding community (Maturana, Hosgood, \& Suhartanto, 2005); Andersson, Ravikumar, Mwangi, Guariguata, \& Nasi, 2011; Suprapto, 2014). Regulation of the Minister of Forestry of the Republic of Indonesia Number P.39/Menhut-II/2013 concerning Empowerment of Local Communities through Forestry Partnerships, provides flexibility for communities to manage forests while still paying attention to ecological aspects and the concept of sustainable forest management.

UPTD KPH Tarakan has facilitated 2 Association of Forest Farmer Groups (Gapoktanhut) and legalized its land-use activities through a Forestry Partnership permit. The two Gapoktanhut are Gunung Slipi and Lestari Gunung Selatan with a partnership area of 105 hectares each. There are 31 members of Gapoktanhut Gunung Slipi with the Social Forestry Business Group (KUPS) in the form of non-timber forest products and agroforestry, while Lestari Gunung Selatan has 37 members with KUPS for environmental services and agroforestry.

The community's business commodities in utilizing land with an agroforestry/agrosilvopastoral/silvofishery pattern consist of crops such as spinach, mustard greens, eggplant, kale, long beans, cucumber, cassava, chilies, and corn. Meanwhile, the community tends to choose MPTs such as fruit trees, including durian, lai, mango, jackfruit, rambutan, gaharu, and eucalyptus. Many types of MPTs are developed by the community 
because these types of plants can produce commodities that have economic value. Several research results show a real contribution from MPTs crop yields to the income of farmers who manage land using agroforestry (Asmi et al, (2013); Nadeak et al, (2013); Tiurmasari et al, (2016); Syofiandi et al, (2016); Kholifah et al, (2017); Hanum et al, (2018) and Wanderi et al, (2019)).

Non-timber forest products as a form of group business synergize with the development of eucalyptus species (Melaleuca leucadendron) as the flagship program of UPTD KPH Tarakan in forest and land rehabilitation activities. Currently, more than 200 ha of eucalyptus (Melaleuca leucadendron) plants have been planted and a large seed garden of $83 \mathrm{ha}$. This activity also involves the community developing eucalyptus on their cultivated lands. The potential and prospects for the development of eucalyptus (Melaleuca leucadendron) in HLPT are quite good. Based on the results of the Mulawarman University laboratory tests in 2015, the cineol content reached 70-90\% (Anonymous, 2020). However, at the farmer level the selling price of eucalyptus is still low, namely Rp1,000/kg, so not all farmers are interested in cultivating this type of plant. Compared to the production of other types of crops, the income obtained from the eucalyptus oil business is lower. In addition to eucalyptus plants (Melaleuca leucadendron), non-timber forest products that are also starting to be developed are the cultivation of honey from kelulut bees (Trigona sp). Meanwhile, the group's business in the form of environmental services has not been running so far because the ecotourism development of Binalatung On-farm Reservoir which is in the HLPT has just completed the DED.

The achievement of the objectives of forestry partnerships is highly dependent on several indicators that influence the successful implementation of forestry partnerships in the field. An assessment of the implementation of the partnership that has been running needs to be done to see a portrait of the gap between the existing conditions and the expected conditions.

One of the indicators used to understand the principles in forestry partnerships is the clarity of the physical boundaries of the forestry partnership management area (Abidin et al, 2018). On community-managed land following the Decree of Recognition and Protection of Forestry Partnership (KULIN KK) with an area of 105 hectares each, until now there has been no physical sign in the form of clear and permanent stakes indicating the boundaries of land managed by the community as well as boundaries of managed land between group members. Approaching the three years of the journey of the forestry partnership, the physical boundary in the form of a permanent stake has not yet become the concern of the forest manager in this land UPTD KPH Tarakan as an anticipation of the opportunity for land expansion by Gapoktanhut members or outside members who have the potential to take advantage of the unclear boundaries of the managed land. Below is a snapshot of the current forestry partnership land governance at HLPT.

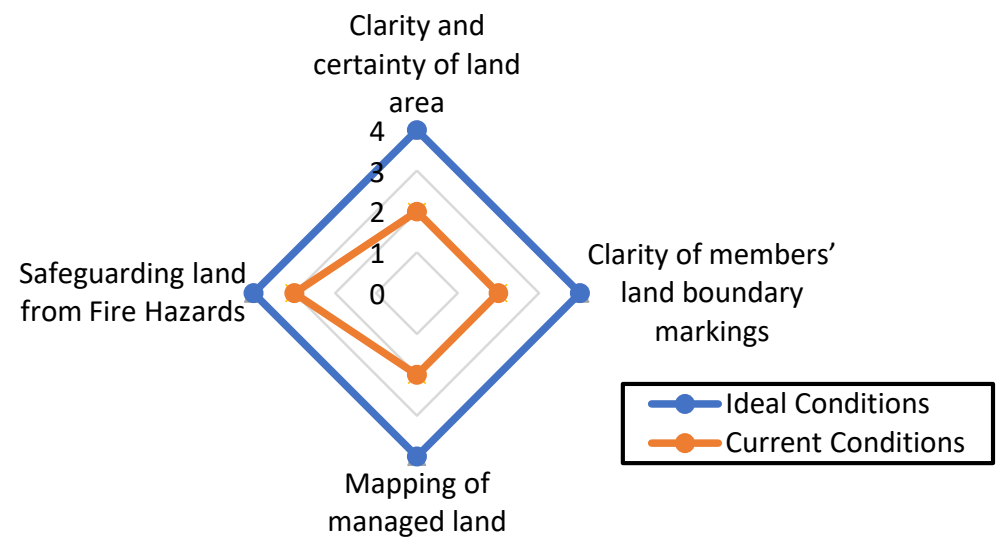

Figure 1 - The Gap in Land Governance Capacity 
In addition to safeguarding managed land by installing clear physical stakes, safeguarding managed land against fire hazards also needs attention, especially from farming communities who are responsible for the safety of managed land and its surroundings from the dangers of forest and land fires. HLPT is very vulnerable to the dangers of forest and land fires, where up to 2016 there had been 10 fires. The causes of these fires were various, ranging from community activities and forest or land which burned by itself as a result of the dry season that hit Tarakan City.

Increased awareness and participation of land tenure communities in protected forests as a form of shared responsibility must always be improved. One of the clauses in the KULIN $\mathrm{KK}$ is implementing forest security and protection, where this responsibility is also stated in the Regulation of the Minister of Environment and Forestry No. P.32/MenLHK/Setjen/Kum.1/3/2016 concerning Forest and Land Fire Control in Article 95.

Institution is one of the important factors in determining the success of the partnership program. The meaning of institution is not the only institution in terms of organization or hardware, but also includes software, rules of the game, exemplary, trust, and consistency of policies applied (Peters, 2000). The influence of institutional activities can be seen from the internal and external institutions. Institutional concerns the structure and function of group institutions, group rules, and the design of programs and activities.

The organizing of Gapoktanhut, both Gunung Slipi and Lestari Gunung Selatan, has not been running and well organized. This is inseparable from the absence of a mutually agreed-upon organization's statutes (AD) and Bylaws (ART) as group policy guidelines. The following are the gaps in the implementation of forestry partnerships from the institutional aspect.

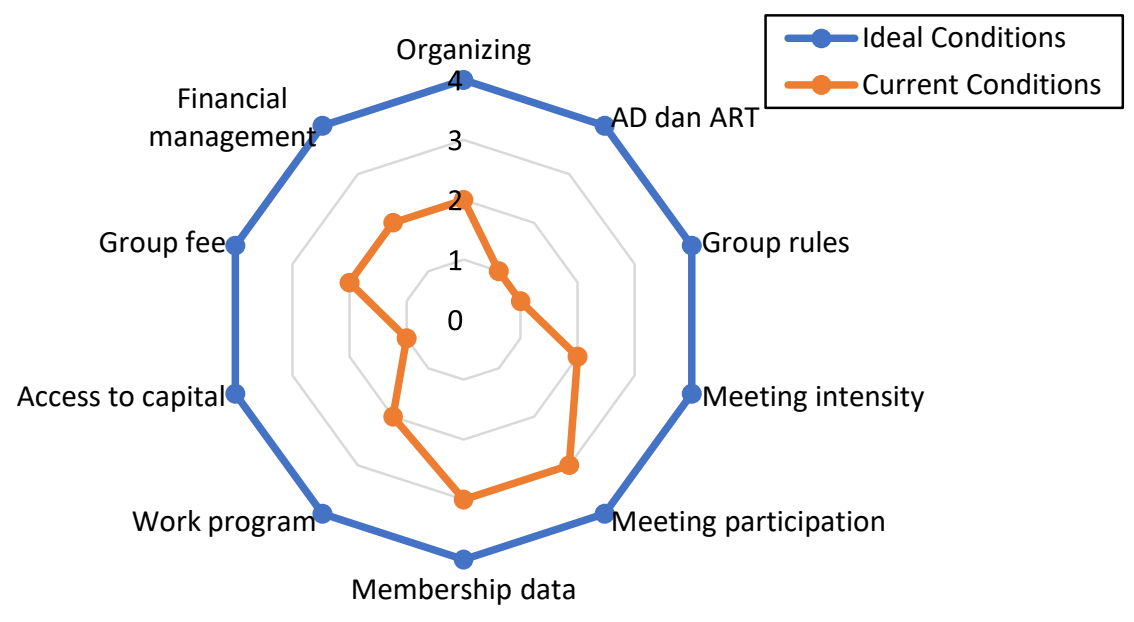

Figure 2 - Institutional Capacity Gap

The process of administering the organization, starting from secretarial, documenting, is also not well organized. Bookkeeping and group administration systems do not record important data and information related to membership. Member data only administer data and information following what is stated in the member's Identity Card. Whereas data regarding the land area, land coordinates, type of commodity cultivated is important as an indicator in monitoring and evaluating the existing partnerships. In implementing forestry partnerships, forest managers and permit holders face many problems at the site level, including those closely related to institutional issues, partnership products, financing, rights and obligations, and profit-sharing (Wiati et al., 2020).

The existence of a strong group with integrity is needed. Accountability and transparency as stated in the Minister of Forestry Regulation No: P.39/Menhut-II/2013 can be realized from a neat and orderly financial administration. Administration of supervision 
(monitoring and evaluation) also has a fairly strong role in maintaining order in the institution, especially in the secretarial process of the institution. The good administrative arrangement, resulting in good and accountable administrative governance (Adnan et al, 2015).

The quality of $\mathrm{KPH}$ management is determined by the human resources in it. $\mathrm{KPH}$ require professional management and this can only be carried out by smart and skilled human resources. Within the framework of management transformation, the UPTD KPH Tarakan HR must be able to carry out various breakthroughs, both technical breakthroughs, business breakthroughs, institutional breakthroughs, and breakthroughs to participate in improving the regulation of forest resource management.

The $\mathrm{KPH}$ human resources who are most concerned with the running of the partnership in forestry and forest protection are field extension workers and forestry police. Following their main duties, forestry extension agents carry out preparation, implementation, development, monitoring, evaluation, and reporting of forestry extension activities that are directly related to the community.

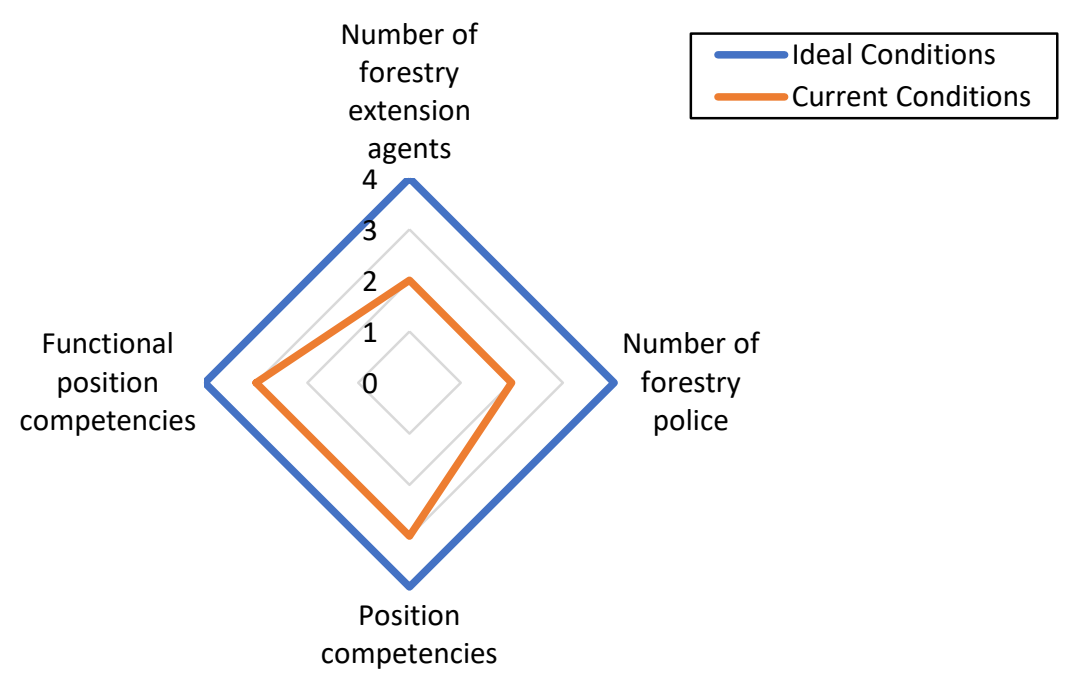

Figure 3 - The Gap in Human Resources Capacity of UPTD FMU Tarakan

Permenhut No: P.57/Menhut-II/2014 Regarding Guidelines for Forest Farmers Group Development Article 24 states that KTH guidance is carried out by forestry extension agents and supervisory agencies. Furthermore, Article 25 states that Forest Farmers Group guidance carried out by forestry extension agents includes: a) manage institutions; b) manage the area, and c) manage the business. Furthermore, Article 27 states in detail the development of Forest Farmers Group institutional management.

The number of forestry extension agents at the UPTD KPH Tarakan is very limited and has not yet fulfilled the ideal conditions. This especially occurred after the issuance of the Governor of North Kalimantan Regulation No. 66 of 2018 concerning the Organization and Implementation of Regional Technical Units at the North Kalimantan Forestry Service, where UPTD KPH Class A Tarakan City previously only had a work area of Unit VI Tarakan covering an area of $\pm 7,200$ hectares, then based on the Pergub, it received an additional work area for Unit VIII Delta Kayan covering an area of $\pm 140,334$ hectares. There are 20 employees in UPTD KPH Tarakan with 3 extension workers and 5 Forestry Police. Apart from civil servants, there are also Forestry Service professionals. The number of available field workers is still not following the wide coverage of the existing work area. Apart from that, other social forestry schemes such as village forests in several villages must also be handled by a limited number of forestry extension workers. In terms of quality, the existing functional staff also do not meet the competency standards as demanded by the Minister of the Forestry Republic of Indonesia No: P. 42/Menhut-II/2011 concerning Competency Standards in Forestry Technical Fields in Protected Forest Management Units and Production Forest Management Units. 
Farmers who are members of Gapoktanhut have a relatively low level of education, that is, most of them only go to the primary school level. Therefore, intense socialization efforts are needed regarding the concept of partnership that is currently being carried out, the importance of the function of protected forest areas, and the rights and obligations that must be fulfilled while utilizing the land. Another thing that is also important is the awareness that the land cultivated by farmers is not owned and will not belong. The community only has status as cultivators for a certain period, namely 15 years, and will be evaluated every 5 years. During the partnership period, the land may not be converted, traded, used, and expanded without permission from the Minister of Environment and Forestry.

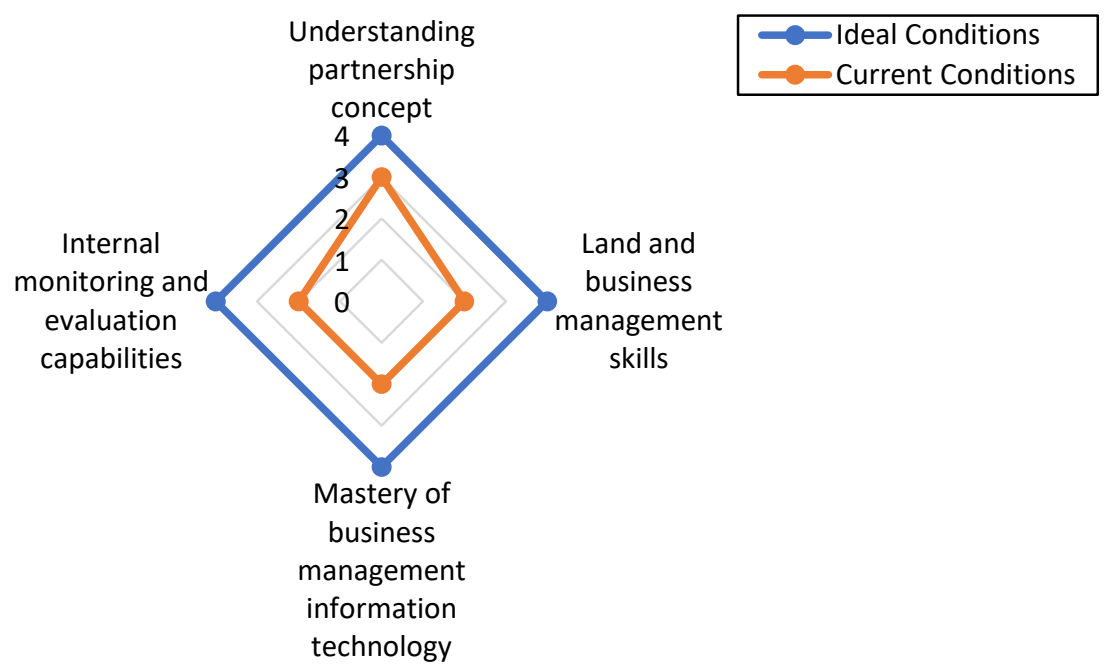

Figure 4 - The Gap in Community Human Resource Capacity

Partner communities who are members of Gapoktanhut are land cultivators who have cultivated land in protected forest areas before the realization of the forestry partnership program. Thus, the community is quite experienced. However, in the context of forestry partnerships, land tenants who are members of Gapoktanhut have special goals, rights, and obligations that must be fulfilled. This means that the ability and experience to cultivate the land for the economic benefit of the family is not sufficient. Farmers must also have adequate knowledge and abilities on how to manage land which not only provides economic benefits but also must pay attention to the aspects of the sustainability of the HLPT function, manage the organization, business, and finance as well as carry out internal evaluation and monitoring.

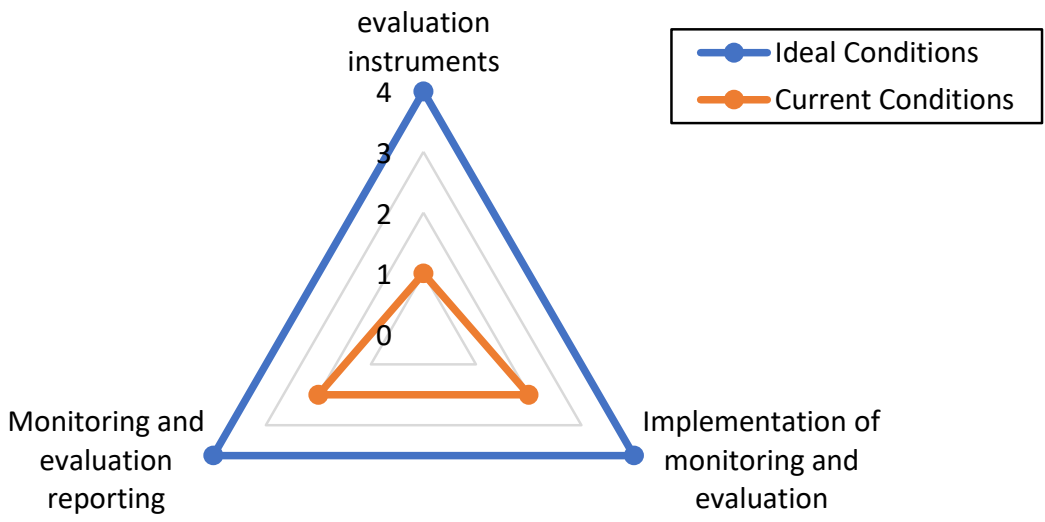

Figure 5 - Gaps in the Implementation of Monitoring and Evaluation 
Monev is very important during the period of forestry partnership permit and cooperation agreement. According to Sudarsono (2016), monitoring can be carried out for a certain period, for example, once every 3 or 4 months, while evaluation can be done once a year or according to applicable regulations. The results of Monev can serve as the basis for temporary or permanent license revocation. Monev must be carried out with clear and measurable procedures, criteria, and benchmarks. Therefore, planning and determining the work program in the general plan (RU) and annual work plan (RKT) of the forestry partnership program is very important, to determine the success of the management plan achievement by building evaluation tools in the form of success indicators.

Monitoring and evaluation activities, both by the KPH and by the community, have not yet proceeded as they should. This is due, among other things, to the absence of RU and RKT which can be used as benchmarks in assessing the achievements of the successful partnership carried out by both parties. Besides, the lack of skilled human resources in compiling Monev instruments and indicators of success is also a weakness that must be given strengthening so that the achievement of forestry partnership achievements can be realized.

\section{CONCLUSION}

Implementation evaluation of the forestry partnership in HLPT is carried out on aspects of land management, institutions, human resource capacity of the community, and the UPTD $\mathrm{KPH}$ Tarakan as well as monitoring and evaluation. All aspects with their indicators show the gap between the current condition and the expected ideal condition.

Strengthening and assisting land governance, institutional and human resource capacity of partner parties as well as monitoring and evaluation must be carried out to achieve the objectives of forestry partnerships in HLPT.

\section{REFERENCES}

1. Adnan Hasantoha, Hasbi Berliani, Gladi Hardiyanto, Suwito, Danang Kuncoro Sakti. 2015. Pemberdayaan Masyarakat melalui Kemitraan Kehutanan. Kemitraan Partnership

2. Andersson, K., Ravikumar, A, Mwangi, E., Guariguata, M., \& Nasi, R. (2011). Menuju Bentuk Kerja Sama Yang Lebih Berkesetaraan. Kontribusi Masyarakat Lokal Bagi Konsesi Pengusahaan Kayu (Occasional Paper 72). Bogor: Center for International Forestry Research (CIFOR).

3. Anonim, 2014. Rencana Pengelolaan Hutan Jangka Panjang FMUL Tarakan Tahun 2015 - 2024. Tarakan

4. Anonim, 2020. Produksi Minyak Kayu Putih di Tarakan Meningkat. https://korankaltara.com/produksi-minyak-kayu-putih-di-tarakan-meningkat.

5. Asmi, M. T., Qurniati, R., \& Haryono, D. (2014). Komposisi Tanaman Agroforestri and Kontribusinya Terhadap Pendapatan Rumah Tangga Di Desa Pesawaran Indah Kabupaten Pesawaran Lampung. Jurnal Sylva Lestari, 1(1), 55-64.

6. Fandeli, C., dkk., 2004. Perhutanan Hutan, Fakultas Kehutanan, Universitas Gadjah Mada, Yogyakarta

7. Hanum, I. M., Qurniati, R., \& Herwanti, S. (2018). Peran Wanita Pedesaan Hutan Dalam Peningkatan Pendapatan Rumah Tangga. Jurnal Sylva Lestari, 6(3), 36-45.

8. Kholifah, U. N., Wulandari, C., Santoso, T., \& Kaskoyo, H. (2017). Kontribusi Agroforestri Terhadap Pendapatan Petani Di Kelurahan Sumber Agung Kecamatan Kemiling Kota Bandar Lampung. Jurnal Sylva Lestari, 5(3), 39-47

9. Maturana, J., Hosgood, N., \& Suhartanto, A.A. (2005). Menuju Kemitraan Perusahaan Masyarakat: Elemen-Elemen Yang Perlu Diperimbangkan Oleh Perusahaan Perkebunan Kayu Di Indonesia (Working Paper No. 29 (1). Bogor: Center for International Forestry Research (CIFOR). 
10. Nadeak, N., Qurniati, R., \& Hidayat, W. (2014). Analisis Finansial Pola Tanam Agroforestri di Desa Pesawaran Indah Kecamatan Padang Cermin Kabupaten Pesawaran Provinsi Lampung. Jurnal Sylva Lestari, 1(1), 65-74.

11. Peters, B. G. 2000. Institutional Theory: Problem and Prospects. 69 Political Science Series. Institute for Advanced Studies. Vienna

12. Sudarsono, D. 2016. Panduan and Monitoring PHBM. Yayasan Masyarakat Nusa Tenggara (SAMANTA).

13. Suprapto, E. 2014. Kemitraan Kehutanan di Jawa Barat-Banten. Policy Paper Arupa, 1: $1-22$.

14. Syofiandi, R. R., Hilmanto, R., \& Herwanti, S. (2016). Analisis Pendapatan and Kesejahteraan Petani Agroforestri di Kelurahan Sumber Agung Kecamatan Kemiling Kota Bandar Lampung. Jurnal Sylva Lestari, 4(2), 17-26

15. Tiurmasari, S., Hilmanto, R., \& Herwanti, S. (2016). Analisis Vegetasi and Tingkat Kesejahteraan Masyarakat Pengelola Agroforestri Di Desa Sumber Agung Kecamatan Kemiling Kota Bandar Lampung. Jurnal Sylva Lestari, 4(3), 71-82.

16. Wanderi, W., Qurniati, R., \& Kaskoyo, H. (2019). Kontribusi Tanaman Agroforestri terhadap Pendapatan and Kesejahteraan Petani. Jurnal Sylva Lestari, 7(1), 118-127.

17. Wiati, C. B, Yuni Indriyanti, \& Eddy Mangopo Angi (2020). Implementasi Kemitraan Kehutanan and Permasalahannya Di Tingkat Tapak. Bersama Membangun Perhutanan Sosial. IPB Press Bogor

18. Yusran, 2012. Hutan and Masyarakat: Tinjauan Dalam Perspektif Kebijakan and Sosial Ekonomi. IPB Press. Bogor. 